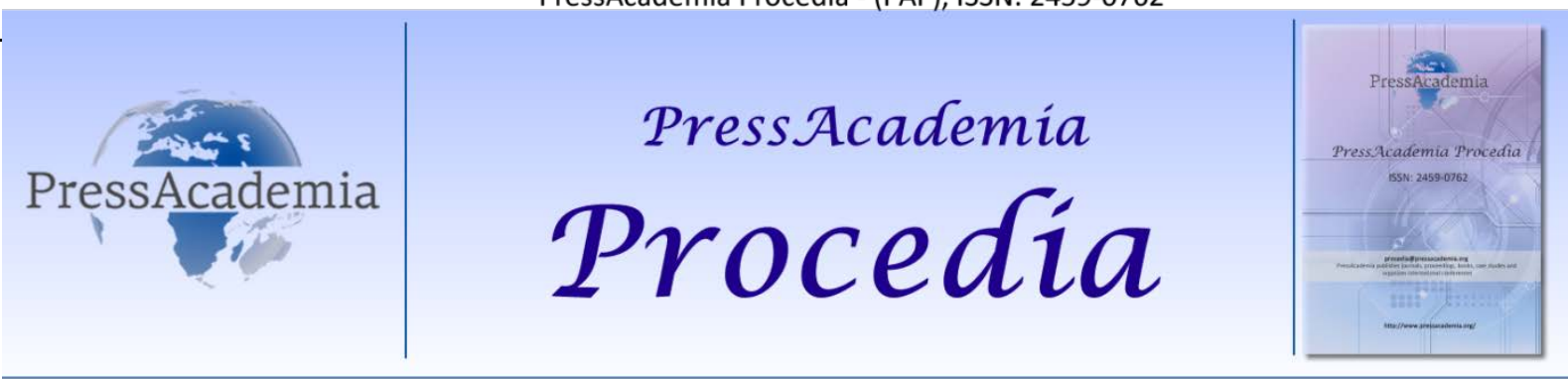

Global Business Research Congress (GBRC), May 26-27, 2016, Istanbul, Turkey.

\title{
IS THERE PERSONALITY IMPACT ON THE EMOTIONAL LABOUR? AN APPLICATION IN SPECIAL EDUCATION AND REHABILITATION CENTERS
}

\section{DOI: 10.17261/Pressacademia.2016118659}

\section{Zehra Yeni ${ }^{1}$, N. Derya Ergun Ozler ${ }^{2}$}

${ }^{1}$ Dumlupınar Üniversitesi. zehraayeni@gmail.com

${ }^{2}$ Dumlupınar Üniversitesi, deryaergun69@hotmail.com

\begin{abstract}
The main purpose of this research is to determine the impact of personality characteristics on dimensions of emotional labor. Personality scale is used in research which is developed by Benet - Martinez and John in 1998 and done the structure and validity study of the scale by Sümer et al (2005). The scale comprises 44 statements. The emotional labor is a scale consisting of 13 statements. The scale is developed by Diefendorff et al in 1990 and done the structure and validity study of the scale by Basım and Beğenirbaş (2012). The research population is engaged in Kütahya form of Special Education and Rehabilitation Center 152 employees. Through a questionnaire method from the main mass is obtained 119 reliable data. SPSS software was utilized to analyze the data. The analyzes of results have been detected that characteristics have affected in-depth and intimate behaviour which is dimension of emotional labor whereas superficial behaviour dimension haven't been affected by it.
\end{abstract}

Keywords: Five factor personality, emotional labor, personality, behavior

JEL Codes: M10, M19

\section{KişiLiĞiN DUYGUSAL EMEK ÜZERINDE ETKISI VAR MIDIR? ÖZEL EĞiTiM VE REHABILITASYON MERKEZLERINDE BIR UYGULAMA}

\section{ÖZET}

Bu araştırmanın temel amacı, kişilik özelliklerinin duygusal emeğin boyutları üzerindeki etkisini belirlemektir. Araştırmada kullanılan kişilik özellikleri ölçeği Benet - Martinez ve John' un 1998 yılında geliştirdikleri, Sümer ve arkadaşları (2005) tarafından yapı ve geçerlilik çalışması yapılan 44 ifadeli ölçektir. Duygusal emek ölçeği ise; Diefendorff ve arkadaşları' nın 2005 yılında geliştirdikleri, Basım ve Beğenirbaş' ın (2012) yapı geçerlilik çalışmasını yaptığı 13 ifadeden oluşan ölçektir. Araştırmanın evrenini Kütahya İlinde faaliyette bulunan 152 Özel Eğitim ve Rehabilitasyon Merkezi çalışanı oluşturmaktadır. Tamsayım yöntemiyle elde edilen ana kütleden anket yoluyla 119 sağlam veriye ulaşıımışır. Verilerin analizinde SPSS programından faydalanılmıştır. Yapılan analizler sonucunda; kişilik özelliklerinin duygusal emek boyutlarından derinlemesine davranış ve samimi davranış boyutunu etkilediği, yüzeysel davranış boyutunu ise etkilemediği tespit edilmiştir.

Anahtar Kelimeler: Beş faktör kişilik, duygusal emek, kişilik, davranış

JEL Kodları: M10, M19 


\section{GíRiş}

Günümüzde hizmet sektörünün öneminin artması, örgütlerde duyguları önemli bir faktör haline getirmiştir. İşletmeler rekabet avantajını sağlamanın yolu olarak hizmetin kalitesinden önce müşteri memnuniyetinin önemli bir etken olduğunu düşünmeye başlamıştır. Bu nedenle artık işverenler çalışanlarından sadece bedensel ve zihinsel emek sarf etmelerini değil, bunların yanında duygusal emek göstermelerini de istemektedir. Bu ise birbirinden farklı kişilik özelliklerine sahip olan bireylerin belirlenmiş duygu gösteriminde bulunması anlamına gelmektedir.

Günümüz toplumlarında genel işgücünün \% 50' den fazlasının hizmet sektöründe olduğu görülmektedir. Üretimde belirli bir standardın yakalanması, rakipler açısından fark yaratıcı unsur olarak ifade edilen üretimin yanında, sunulan hizmetlerin kalitesi, müşteri memnuniyeti vb. unsurların önemini artırmıştır. İşletmelerin bu unsurların nasıl sağlanacağına yönelik yaptıkları araştırmalar sonucunda, müşterilerle kurulacak olan duygusal bağların önemli olduğu ortaya çıkmış ve bu maksatla duygusal davranış kuralları geliştirilmiştir. Bu davranış kuralları, çalışan bireylerin belirlenen kurallar çerçevesinde duygularını yönetmelerini ifade etmektedir.

Duyguların belirlenen kurallar çerçevesinde yönetilmesi sonucunda sunulan hizmette üstünlük sağlamak olarak tanımlanan duygusal emeği ilk olarak 1983 yılında Hochschild kullanmıştır. Bu zamana kadar emeğin bir ücret karşılığında alınıp satılabilen bir unsur olması sadece fiziksel ve zihinsel emek türlerini akla getirirken, günümüzde duyguların sarf edilmesi sonucunda meydana gelen duygusal emek olarak akıllarda yer eden yeni bir emek türü oluşmuştur.

Birbirinden farklı kişilik özelliklerine sahip olan bireylerin belirlenmiş davranış kurallarına uyarak aynı davranışları sergilemesi oldukça güç bir durumu ifade etmektedir. Bu çalışmanın temel amacı bireylerin sahip olduğu farklı kişilik özelliklerinin duygusal emek sergilemelerinde etkili olup olmadığını tespit etmektir.

\section{LITERATÜR TARAMASI}

Çalışmanın bu bölümünde kişilik, beş faktör kişilik özellikleri, duygusal emek ve beş faktör kişilik özellikleri ile duygusal emek arasındaki ilişki hakkında bilgi verilecektir.

Kişilik, bireyin farklı durumlarda ve farklı zamanlarda, geniş anlamda ayırt edici ve tutarlı bir şekilde gösterdiği psikolojik özellikleridir (Buchanan ve Huczynski, 1997). Kişiliğin; karakter, mizaç ve yetenek olmak üzere üç bileşeni bulunmaktadır. Karakter; kalıtsal olmayan özelliklerin birey tarafından erken dönemlerde başlanarak sonradan edindiği özellikler olarak tanımlanmaktadır (Adler, 2008: 191-192). Mizaç, duygulara dayalı yeteneklerin ve alışkanlıkların bir araya getirilmesinin altında yatan ilişki kurma, duyumsama süreçlerini (Cloninger ve Svrakic, 2000: 241), yetenek ise; bireyin sahip olduğu zihinsel ve bedensel özellikleri ifade etmektedir (Eroğlu, 2011: 221).

1985 yılında özellikler yaklaşımını benimseyen Costa ve McCrae, faktör olarak adlandırdıkları değişkenleri büyük insan topluluklarına uygulamışlar ve çok yönlü olarak ölçüm yapıp ardından kişiliğin beş faktörden oluştuğunu belirtmişlerdir. Illk çalışmalarının sonucunda NEO-PI olarak adlandırdıkları kişiliğin üç boyutunun (deneyime açıklık, duygusal dengesizlik ve dışa dönüklük) olduğunu ifade etmişlerdir (Apple, 2011: 14). Daha sonraki çalışmalarının sonucunda ise kişiliğin beş ana boyutunu ortaya koymuşlardır. Bu boyutlar ise; dışa dönüklük, duygusal dengesizlik, uyumluluk, sorumluluk ve gelişime açıklıktır (Somer ve Goldberg, 1999: 431-450). Dışadönüklük; sosyalleşme derecesi yüksek, diğer bireylerle iletişime geçmekten hoşlanan, konuşmayı seven, içinde bulundukları durumları abartmaya meyilli, tutkulu, hırslı ve çevresindekilere göre baskın, iddialı bireyleri ifade etmektedir (Barrick ve Mount, 1991: 5, Yoon, 1997: 31, Trouba, 2007: 9). Duygusal dengesizlik; olumlu psikolojik uyum ve duygusal dengenin eksik olma durumunu ifade etmektedir ve bireyin kişiliğinde bulunan duygusal dengeye ait bilgileri ortaya koymaktadır (Trouba, 2007: 9). Bununla birlikte; bireylerin yüksek stres ve baskı altında bulundukları durumlarda duygusal dengesizlik boyutuna uygun davranış şekilleri sergileyecekleri de ifade edilmektedir (Perry, 2003: 5). Uyumluluk; işbirliği ile hareket eden, nazik, esnek, rekabetten öte birlikte başarma yanlısı, sevecen, dostane, yardımsever gibi olumlu özelliklere sahip kişilik özelliklerini ifade etmektedir (Moody, 2007: 28, Perry, 2003: 5). Sorumluluk ise; görev bilincine sahip, düzenli, kabiliyetli, ihtiyatlı, başarmak için mücadele güdüsüne sahip, öz disiplinli bireyler olarak ifade edilmektedir (Shaye, 2009: 
9). Son olarak gelişime açıklık ise; zeki, bilgili, hayal gücü yüksek, sanata karşı ilgili, duygusal, fikir sahibi, estetik, aktif, fantastik gibi kişilik özelliklerini ifade etmektedir (Church, 1993: 10, Shaye, 2009: 9).

Duyguların hayatın içinde bulunan bir konu olmasının ötesinde iş hayatında da önemli bir yere sahip olduğuna yönelik ilk çalışmayı 1983 yılında Amerikalı Sosyolog Arlie R. Hochschild " The Managed Heart: Commercialization of Human Feeling" (Yönetilen Kalp: İnsan Duygularının Ticarileştirilmesi) adlı eseri ile ortaya koymuştur (Hochschild, 1983: 188-119). Duygusal emek, mesleğin veya örgütün gösterim kurallarını karşılamak amacıyla duygusal gösterimlerin rol yapma, abartma ya da bastırma yoluyla dönüştürülmesi durumu olarak ifade edilmektedir (Grandey, 2000). Duygusal emek yüzeysel davranış, derinlemesine davranış ve samimi davranış olmak üzere üç boyuttan oluşmaktadır. Yüzeysel davranış; hissedilmekte olan duygu ile gösterilmesi gereken duygunun arasında farklılık olduğu durumlarda sergilenen duygu olarak ifade edilmektedir (Hochschild, 1983: 37, Ashforth ve Humphrey, 1993: 92 - 93). Bu davranış türünde beklenilen, olumlu duyguların taklit edilmesi olumsuz duyguların ise saklanmasıdır (Diefendorff vd., 2005: 340). Derinlemesine davranış; gösterilmesi arzulanan duygunun hissedilmesi için bireyin içsel olarak göstermiş olduğu çaba olarak tanımlanmaktadır (Hochschild, 1983: 38, Ashforth ve Humphrey, 1993: 93). Bireyin sergilemek zorunda olduğu duyguyu hissetmeye çalışması olarak da ifade edilmektedir. Samimi davranış ise; bireylerin sergilemeleri istenen davranışları zaten hissediyor olmaları durumunda meydana gelen davranış türü olarak tanımlanmaktadır (Ashforth ve Humphrey, 1993: 94).

Çalışan bireylerin birbirlerinden farklı olmasının temelinde yatan kişilik unsurunun duyguların ifade edilmesinde önemli bir etkiye sahip olduğunu söylemek mümkündür (Hochschild, 1983: 33, Garndey, 2003: 90). Bu çerçevede düşünüldüğünde beş faktör kişilik özellikleri ile duygusal emek arasındaki ilişkiyi belirlemeye yönelik çalışmaların yapıldığı görülmektedir. Yapılan bu çalışmalara örnek olarak Garandey' in 2003 yılında, Tan vd.' nin 2003 yılında, Tews ve Glomg' un 2004 yılında, Diefendorf vd.' nin 2005 yılında, Barrick ve Mount' un 2005 yılında, Kim' in 2008 yılında, Cheung ve Tang' ın 2009 yılında, Kiffin - Petersen vd.' nin 2011 yılında, Beğenirbaş ve Yalçın' nın 2012 yılında, Basım vd.' nin 2013 yılında yapmış oldukları çalışmalar gösterilebilir.

Barrick ve Mount' un 2005 yılında, Beğenirbaş ve Yalçın' nın 2012 yılında yaptıkları çalışmaya göre dışa dönük bireylerin samimi davranış sergilediği sonucuna ulaşılmıştır. Cheung ve Tang' ın 2009 yılında, Diefendorf vd' nin 2005 yılında, Kiffin - Petersen ve arkadaşlarının 2011 yılında, Kim’ in de 2008 yılında yapmış oldukları çalışmalarda dışa dönük bireylerin derinlemesine davranış sergilediği tespit edilmiştir.

Difendorff ve arkadaşlarının 2005 yılında, Tan ve arkadaşlarının 2003 yılında, Basım ve arkadaşlarının da 2013 yılında yapmış oldukları çalışmaların sonuçları duygusal dengesizlik kişilik özelliklerine sahip olan bireylerin yüzeysel davranış sergilediklerini göstermiştir.

Austin vd.' nin (2008), Diefendorff vd.'nin (2005), Kiffin - Petersen vd.' nin (2011), Beğenirbaş ve Yalçın' In (2012), Basım vd.' nin (2013) yapmış oldukları çalışmalarda da uyumluluk kişilik özelliklerine sahip olan bireylerin derinlemesine ve samimi davranış sergiledikleri sonucuna ulaşılmıştır.

1991 ve 2005 yıllarında Barrick ve Mount' un, 2000 yılında Grandey' in, 2008 yılında Austin ve arkadaşlarının, 2005 yılında Diefendorff ve arkadaşlarının yapmış oldukları çalışmalarda beş faktör kişilik özellikleri boyutlarından sorumluluk boyutunun farklı duygusal emek gösterimlerine işaret ettiği fakat iş başarımı hususunda bireylerin derinlemesine davranış boyutunu benimsediklerini tespit edilmiştir. Beğenirbaş ve Yalçın' ın 2012 yılında yapmış olduğu çalışmada sorumluluk kişilik özelliklerine sahip bireylerin samimi davranış sergiledikleri, Basım ve arkadaşlarının 2013 yılında yapmış olduğu çalışmada ise, bazen samimi davranış bazen ise derinlemesine davranış sergiledikleri tespit edilmiştir.

Diefendorff ve arkadaşlarının 2005 yılında, Austin ve arkadaşlarının 2008 yılında, Tan ve arkadaşlarının da 2003 yılında yapmış oldukları çalışmalar kişilik özellikleri boyutlarından gelişime açıklık boyutu ile duygusal emek ve boyutları arasında herhangi bir ilişkinin olmadığı sonucuna ulaşılmıştır. Beğenirbaş ve Yalçın' ın 2012 yılında, Basım ve arkadaşlarının 2013 yılında yaptıkları çalışmalarda ise gelişime açıklık boyutu ile duygusal emek arasında ilişkinin olduğu sonucuna ulaşılmıştır. Beğenirbaş ve Yalçın' ın çalışmasına göre gelişime açıklık kişilik özelliklerine sahip olan bireylerin samimi davranış sergiledikleri, Basım ve arkadaşlarının çalışmasına göre de gelişime açıklık ile derinlemesine ve samimi davranış sergiledikleri sonuçlarına ulaşılmıştır. 
Yapılan çalışmalar beş faktör kişilik özellikleri ile duygusal emek arasında ilişkilerin olduğunu göstermektedir. Fakat çalışmaların sonuçları uygulamanın yapıldığı ülkeye, meslek gruplarına vb. kriterlere göre farklılıklar gösterebilmektedir.

\section{VERI VE YÖNTEM}

Araştırmanın temel amacı beş faktör kişilik özelliklerinin duygusal emek boyutları üzerinde etkisinin olup olmadığını belirlemektir. Bu etkinin ortaya çıkarılması ve sonuçların tespit edilmesi için araştırmaya yönelik model ve hipotezler aşağıdaki gibidir.

\section{Şekil 1: Araştırma Modeli}

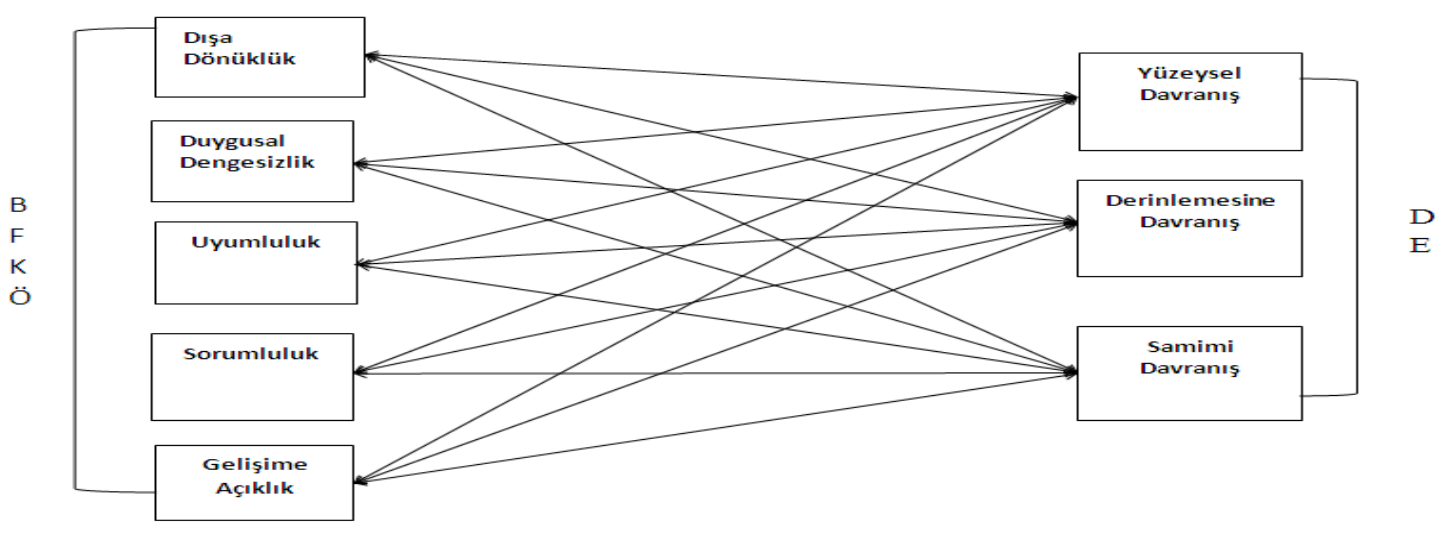

Araştırma modeli doğrultusunda oluşturulan hipotezler aşağıdaki gibidir;

$\mathbf{H}_{1}$ : Beş faktör kişilik özellikleri duygusal emek boyutlarından yüzeysel davranışı etkilemektedir.

$\mathbf{H}_{\mathbf{2}}$ : Beş faktör kişilik özellikleri duygusal emek boyutlarından derinlemesine davranışı etkilemektedir.

$\mathbf{H}_{3}$ : Beş faktör kişilik özellikleri duygusal emek boyutlarından samimi davranışı etkilemektedir.

Araştırmanın evrenini, Kütahya İli merkez ve ilçelerinde bulunan Milli Eğitim Bakanlığına bağlı özel eğitim ve rehabilitasyon merkezlerinde çalışan işgörenler oluşturmaktadır. Bu çalışanlar, her kurumun kendisi tarafından kendi çalışanları olarak istihdam edilmektedirler. Sosyal hizmet alanında çalışan bireylerin yaşlılarla, çocuklarla, bakıma muhtaç engellilerle birebir iletişime geçerken yüksek oranda duygusal emek harcayacakları varsayılarak özellikle bu alanda çalışanlar araştırmaya evren olarak seçilmiştir. Örnekleme yöntemi olarak tamsayım yöntemi kullanılmıştır. Kütahya İli merkez ve ilçelerinde bulanan özel eğitim ve rehabilitasyon merkezlerinde çalışan 152 bireyden oluşan evrende çalışma yapılmıştır. Yapılan çalışma esnasında 152 anket dağıtılmıştır. Dağıtılan 152 anketten 127 anket doldurulmuş olarak geriye dönmüştür. Dağıtılan anketlerden 25 anket geriye dönmemiş, dönüt alınan 127 anketten eksik ve tutarsız olarak doldurulduğu gözlemlenen 8 anket kullanılamaz olarak analizden çıkarılmış ve kullanılabilir olan 119 anketle araştırmanın analizi yapılmıştır. Toplanan anketlerin analizinde ise sosyal bilimler için analiz programı olan SPSS programından faydalanılmıştır.

Araştırmada veri toplama aracı olarak anket yöntemi kullanılmıştır. Anket formu üç bölümden oluşmaktadır. İlk bölümde özel eğitim ve rehabilitasyon merkezlerinde çalışan bireylerin demografik özellikleri hakkında bilgi sağlamak amacıyla oluşturulan 8 ifadeden oluşan sorular bulunmakta, ikinci bölümde toplam 13 ifadeden oluşan duygusal emek ölçeği bulunmakta ve son bölümde ise, bireylerin kişilik özelliklerini belirlemeye yönelik olarak 44 ifadeden oluşan beş faktör kişilik özellikleri anketi bulunmaktadır.

Araştırmada kullanılan Beş Faktör Kişilik Özellikleri Ölçeği Benet - Martinez ve John tarafından 1998 yılında "Beş Faktör Envanteri" (The Big Five Inventory) ismiyle geliştirilmiştir. Ölçek 44 ifadeden oluşmaktadır. Ölçeğin Türkçe' ye uyarlanması ise 2007 yılında Schmitt ve arkadaşları tarafından bireylerin kendilerini tanımlama profilleri konusunda 56 ülkede yapılan bir çalışmanın Türkiye bölümünü Sümer ve arkadaşları 2005 yılında yapmışlardır. Araştırmada kullanılan Duygusal Emek ölçeği 2005 yılında Diefendorff ve arkadaşları tarafından uyarlanmıştır. Bu ölçek 2003 yılında Garndey tarafından, 2000 yılında Krulm ve Geddes tarafından ayrı ayrı geliştirdikleri duygusal emek ölçekleri temel alınarak uyarlanmış ve bazı ifadelerin geliştirilmesi sonucunda 
oluşturulmuştur. Ölçek 13 ifadeden oluşmaktadır. Ölçeğin Türkçe' ye uyarlamasını ise 2012 yılında Basım ve Beğenirbaş” ın "Çalışma Yaşamında Duygusal Emek: Bir Ölçek Uyarlama Çalışması” isimli çalışmasıyla yapılmıştır.

\section{BULGULAR VE TARTIŞMA}

Çalışmanın bu kısmında araştırmaya konu olan örneklemin demografik özellikleri, kullanılan ölçeklere ilişkin güvenilirlik analizi sonuçları, hipotezlerin test edilmesi için yapılan korelasyon ve regresyon analizi sonuçları hakkında bilgi verilecektir.

Tablo 1: Katılımcılara Ait Demografik Özellikler

\begin{tabular}{|c|c|c|c|c|c|}
\hline Cinsiyet & Sayı & $\%$ & Medeni Durum & Sayı & $\%$ \\
\hline Erkek & 52 & 43,7 & Evli & 67 & 56,3 \\
\hline Kadın & 67 & 56,3 & Bekar & 52 & 43,7 \\
\hline Toplam & 119 & 100,0 & Toplam & 119 & 100.0 \\
\hline $20-25$ & 31 & 26,1 & ilköğretim & 13 & 10,9 \\
\hline $26-30$ & 27 & 22,7 & Lise & 12 & 10,1 \\
\hline 41 ve üzeri & 31 & 26,1 & Lisansüstü & 9 & 7,6 \\
\hline Toplam & 119 & 100,0 & Toplam & 119 & 100.0 \\
\hline Aylık Gelir & Sayı & $\%$ & Meslek & Sayı & $\%$ \\
\hline 1000 TL ve altı & 27 & 22,7 & Müdür & 7 & 5,9 \\
\hline $1001-2000$ & 56 & 47,1 & Öğretmen & 62 & 52,1 \\
\hline $\begin{array}{l}\text { Kurumdaki } \\
\text { Çalışma Süresi }\end{array}$ & Sayı & $\%$ & $\begin{array}{l}\text { Meslekte Çalışma } \\
\text { Süresi }\end{array}$ & Sayı & $\%$ \\
\hline 1 yıldan az & 34 & 28,6 & 1 yıldan az & 16 & 13,4 \\
\hline $1-5 \mathrm{yll}$ & 44 & 37,0 & $1-5$ yıl & 30 & 25,2 \\
\hline $6-10$ & 31 & 26,1 & $6-10$ & 36 & 30,3 \\
\hline $11-15$ & 10 & 8,4 & $11-15$ & 10 & 8,4 \\
\hline 16 ve üzeri & 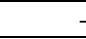 & - & 16 yıl ve üzeri & 27 & 22,7 \\
\hline Toplam & 119 & 100.0 & Toplam & 119 & 100.0 \\
\hline
\end{tabular}

Tablo 1' de görüldüğü gibi araştırmaya katılan özel eğitim ve rehabilitasyon merkezi çalışanlarının \%56,3' lük kısmını kadın katılımcılar, \%26,1' lik kısmını 20-25 yaş grubu, \%47,1' lik kısmını 1001-2000 TL arası gelire sahip, \%37' lik kısmını ise 1-5 yıl arası kurumda çalışan bireyler oluşmaktadır. Bakıldığında katılımcıların \%56,3’ ü evli ve lisans mezunu, \%22,7’ si Memur-Şoför ve \%30,3’ ü 6-10 yıldır mesleklerini yapan bireylerden oluştuğu görülmektedir.

Tablo 2: Ölçeklerin Güvenilirlik Analizi

\begin{tabular}{|l|l|l|}
\hline ÖLÇEKLER & SORU SAYISI & ALFA KATSAYILAR( $(\alpha)$ \\
\hline Beş Faktör Kişilik Özellikleri & 41 & 0,700 \\
\hline Duygusal Emek & 13 & 0,716 \\
\hline
\end{tabular}

Araştırmada kullanılan ölçeklere ilişkin güvenilirlik analizi sonuçları Tablo 2' de görülmektedir. Ölçeklerin güvenilirlik düzeyleri \%70' tir. Araştırmada 44 ifade olarak kullanılan kişilik özellikleri ölçeği yapılan analizler sonucu 41 ifade ye düşürülmüştür. Bu sonuçlar araştırmanın yapılabilmesi için gerekli sınırlar arasında yer almaktadır.

Korelasyon analizi sonuçlarına göre araştırmaya konu olan değişkenler arasındaki incelenmiş ve değişkenler arasında $(p<0,01)$ ve $(p<0,05)$ anlam düzeylerinde çift yönlü ilişkilerin olduğu tespit edilmiştir. 
Tablo 3: Korelasyon Analizi Sonuçları

\begin{tabular}{|c|c|c|c|c|c|c|c|c|}
\hline Değişkenler & $\begin{array}{l}\text { Yüzeysel } \\
\text { Davranış }\end{array}$ & $\begin{array}{l}\text { Derinlemesine } \\
\text { Davranış }\end{array}$ & $\begin{array}{l}\text { Samimi } \\
\text { Davranış }\end{array}$ & $\begin{array}{l}\text { Dişa } \\
\text { Dönüklük }\end{array}$ & Sorumluluk & $\begin{array}{l}\text { Gelişime } \\
\text { Açıklık }\end{array}$ & Uyumluluk & $\begin{array}{l}\text { Duygusal } \\
\text { Dengesizlik }\end{array}$ \\
\hline $\begin{array}{l}\text { Yüzeysel } \\
\text { Davranış }\end{array}$ & 1 & 0,016 & $-0,357$ & $-0,033$ & $-0,158$ & $-0,040$ & 0,005 & 0,033 \\
\hline $\begin{array}{l}\text { Derinlemesine } \\
\text { Davranış }\end{array}$ & & 1 & $0,233^{*}$ & $0,194^{*}$ & $0,319^{* *}$ & 0,010 & 0,100 & 0,054 \\
\hline $\begin{array}{l}\text { Samimi } \\
\text { Davranış }\end{array}$ & & & 1 & $0,431^{* *}$ & $0,444^{* *}$ & $0,285^{* *}$ & $0,308^{* *}$ & 0,096 \\
\hline Dışa Dönüklük & & & & 1 & $0,339^{* *}$ & $0,592^{* *}$ & $0,398^{* *}$ & $0,290^{* *}$ \\
\hline Sorumluluk & & & & & 1 & $0,309^{* *}$ & $0,401^{* *}$ & $0,182^{*}$ \\
\hline Gelişime Açıklık & & & & & & 1 & $0,336^{* *}$ & 0,177 \\
\hline Uyumluluk & & & & & & & 1 & $0,180^{*}$ \\
\hline $\begin{array}{l}\text { Duygusal } \\
\text { Dengesizlik }\end{array}$ & & & & & & & & 1 \\
\hline
\end{tabular}

Tablo $3^{\prime}$ te görüldüğü gibi duygusal emek boyutlarından yüzeysel davranışın kişilik özelliklerinin herhangi bir boyutuyla aralarında ilişki tespit edilememiştir. Duygusal emeğin derinlemesine davranış boyutu ile beş faktör kişilik özellikleri boyutlarından dışa dönüklük ve sorumluluk boyutu arasında pozitif yönlü anlamlı ilişkilerin olduğu $(r=, 19 ; p<, 05),(r=, 31 ; p<, 01)$ tespit edilmiştir. Duygusal emeğin samimi davranış boyutu ile beş faktör kişilik özellikleri boyutlarından dışa dönüklük, sorumluluk, gelişime açıklık ve uyumluluk boyutları ile aralarında pozitif yönlü anlamlı ilişkilerin olduğu $(r=, 43 ; p<, 01),(r=, 44 ; p<, 01),(r=, 28 ; p<, 01),(r=, 30 ; p<, 01)$ tespit edilmiştir.

Araştırmada hipotezlerin test edilmesi için çoklu regresyon yöntemlerinden "Forward Selection" yöntemi kullanılmıştır. Bu başılı altında yapılan analizler ve sonuçları hakkında bilgi verilecektir.

$\mathbf{H}_{1:}$ Beş faktör kişilik özellikleri duygusal emek boyutlarından yüzeysel davranışı etkilemektedir.

Bağımlı değişkenin duygusal emek boyutlarından yüzeysel davranış ve bağımsız değişkenlerin beş faktör kişilik özellikleri olan; dışa dönüklük, duygusal dengesizlik, uyumluluk, öz disiplin ve gelişime açıklık boyutları olduğu çoklu regresyon analizi sonucunda ortaya çıkan modelin anlamlılık düzeyi $p>0,05^{\prime}$ ten büyük olduğu için $\mathrm{H}_{1}$ hipotezi red edilmiştir.

$\mathbf{H}_{\mathbf{2}}$ : Beş faktör kişilik özellikleri duygusal emek boyutlarından derinlemesine davranışı etkilemektedir.

Bağımlı değişkenin duygusal emek boyutlarından derinlemesine davranış ve bağımsız değişkenlerin beş faktör kişilik özellikleri olan; dışa dönüklük, duygusal dengesizlik, uyumluluk, öz disiplin ve gelişime açıklık boyutları olduğu çoklu regresyon analizi sonucunda ortaya çıkan bulgular Tablo 4' de görüldüğü şekildedir.

Tablo 4: Duygusal Emek Boyutlarından Derinlemesine Davranış Boyutuna Iilişkin Çoklu Regresyon Analizi Bulguları

\begin{tabular}{|c|c|c|c|c|c|c|c|}
\hline Model & $\mathrm{R}$ & $\mathrm{R}^{2}$ & S.H. & $F$ & \multicolumn{3}{|c|}{$p$} \\
\hline 1 & 0,319 & 0,102 & 0,842 & 13,285 & \multicolumn{3}{|c|}{0,000} \\
\hline \multicolumn{2}{|c|}{ Model } & B & S.H. & Beta & $\mathbf{t}$ & $\mathbf{p}$ & D-W \\
\hline \multirow[t]{2}{*}{1} & Sabit Terim & 1,139 & 0,714 & - & 1,595 & 0,000 & \multirow[t]{2}{*}{2,159} \\
\hline & Öz Disiplin & 0,726 & 0,199 & 0,319 & 3,645 & 0,000 & \\
\hline
\end{tabular}

Regresyon analizi Forward Sellection yöntemine göre yapıldığı için modeli önemli derecede etkilemeyen değişkenler modelden çıkarılmıştır. Analiz sonucunda etkili olmayan değiş̧enler; dışa dönüklük $(p=0,302)$, duygusal dengesizlik $(p=0,959)$, uyumluluk $(p=0,732)$, gelişime açıklık $(p=0,288)$ istatistiksel olarak anlamsız çıktığı için $(p>0,05)$ modelden çıkarılmışlardır. 
Çoklu regresyon analizi sonucunda tek model oluşmuştur. F istatistiği sonuçları öz disiplin değişkenine ait modelin anlamlı $(p<0,01)$ olduğunu göstermektedir. Tabloda görüldüğü gibi bağımlı değişkendeki değişmeyi açıklayan öz disiplin faktörünün 0,726 değeriyle istatistiksel olarak anlamlı olduğu $(p<0,01)$ sonucuna ulaşılmıştır. Buradan hareketle "beş faktör kişilik özellikleri boyutlarından öz disiplin duygusal emek boyutlarından derinlemesine davranışı etkilemektedir" şeklinde ifade edilmiş ve $\mathrm{H}_{2}$ hipotezi kısmen kabul edilmiştir sonucuna ulaşılmıştır. Bu sonuca göre özel eğitim ve rehabilitasyon merkezi çalışanlarından derinlemesine davranış sergileyen bireylerin en çok beş faktör kişilik özellikleri boyutlarından öz disiplin özelliklerini kişiliğinde bulunduran bireylerin olduğu söylenebilmektedir.

Oluşan modelde derinlemesine davranışın \%10, 2' sini kişiliğin açıkladığı görülmektedir. Yani derinlemesine davranışın sergilenmesinde etkili olan faktörlerin \%10,2' si kişilik özelliklerinden oluşmaktadır. Buradan hareketle derinlemesine davranışın oluşmasını \% 10,2 oranında kişilik özellikleri sağlamakta iken \% 89,8 oranında farklı değişkenler sağlamaktadır.

Bağımlı değişkenin duygusal emek boyutlarından samimi davranış ve bağımsız değişkenin beş faktör kişilik özellikleri olan; dışa dönüklük, duygusal dengesizlik, uyumluluk, öz disiplin ve gelişime açıklık boyutları olduğu çoklu regresyon analizi sonucunda ortaya çıkan bulgular Tablo 5’ te görüldüğü şekildedir.

Tablo 5: Duygusal Emek Boyutlarından Samimi Davranış Boyutuna illişkin Çoklu Regresyon Analizi Bulguları

\begin{tabular}{|c|c|c|c|c|c|c|c|}
\hline Model & $\mathrm{R}$ & $\mathrm{R}^{2}$ & S.H. & $\mathrm{F}$ & \multicolumn{3}{|c|}{$p$} \\
\hline 1 & 0,444 & 0,197 & 0,734 & 28,730 & \multicolumn{3}{|c|}{0,000} \\
\hline 2 & 0,535 & 0,286 & 0,695 & 23,242 & \multicolumn{3}{|c|}{0,000} \\
\hline \multicolumn{2}{|c|}{ Model } & B & S.H. & Beta & $\mathbf{t}$ & $\mathbf{p}$ & D-W \\
\hline \multirow[t]{2}{*}{1} & Sabit Terim & 0,719 & 0,623 & - & 1,144 & 0,000 & \multirow[t]{2}{*}{-} \\
\hline & Öz Disiplin & 0,932 & 0,174 & 0,444 & 5,360 & 0,000 & \\
\hline \multirow[t]{3}{*}{2} & Sabit Terim & $-0,679$ & 0,694 & - & $-0,978$ & 0,000 & \multirow[t]{3}{*}{1,717} \\
\hline & Öz Disiplin & 0,706 & 0,175 & 0,337 & 4,035 & 0,000 & \\
\hline & Dışa Dönüklük & 0,655 & 0,172 & 0,317 & 3,802 & 0,000 & \\
\hline
\end{tabular}

Regresyon analizi Forward Sellection yöntemine göre yapıldığı için modeli önemli derecede etkilemeyen değişkenler modelden çıkarılmıştır. Analiz sonucunda etkili olmayan değişkenler; duygusal dengesizlik $(p=0,442)$, uyumluluk $(p=0,492)$, gelişime açıklık $(p=0,918)$ değişkenler istatistiksel olarak anlamsız çıktığı için ( $p>0,05)$ modelden çıkarılmışlardır. Geriye kalan iki değişkenle analiz yapılmıştır.

Çoklu regresyon analizi sonucunda iki model oluşmuştur. F istatistiği sonuçları iki modelinde anlamlı $(p<0,001)$ olduğunu göstermektedir. Tabloda görüldüğü gibi bağımlı değişkendeki değişmeyi açıklayan öz disiplin faktörünün 0,706 ve dışa dönüklük faktörünün 0,655 değeriyle istatistiksel olarak anlamlı oldukları $(p<0,001)$ sonucuna ulaşılmıştır. Buradan hareketle, "beş faktör kişilik özellikleri boyutlarından dışa dönüklük duygusal emek boyutlarından samimi davranışı etkilemektedir" ve "beş faktör kişilik özellikleri boyutlarından öz disiplin duygusal emek boyutlarından samimi davranışı etkilemektedir" şeklinde ifade edilmiş ve $\mathrm{H}_{3}$ hipotezi kısmen kabul edilmiştir sonucuna ulaşılmıştır. Bu sonuca göre özel eğitim ve rehabilitasyon merkezi çalışanlarından samimi davranış sergileyen bireylerin en çok beş faktör kişilik özellikleri boyutlarından öz disiplin özelliklerini kişiliğinde bulunduran bireylerin olduğunu daha sonra ise, kişiliğinde dışa dönük kişilik özelliklerini bulunduranların samimi davranış sergiledikleri söylenebilir. İlk modelde öz disiplin samimi davranışın \%19,7' sini açıklamaktadır. Oluşturulan ikinci modelde öz disiplin ve dışa dönüklük ile samimi davranış arasında pozitif yönlü bir ilişki vardır. Bununla birlikte bu iki değişkenin samimi davranış üzerindeki değişimin \%28,6 sini açıkladığı sonucuna ulaşılmıştır.

\section{SONUÇ}

Bu çalışma bireylerin sahip olduğu kişilik özellikleri ile göstermiş oldukları duygusal emek arasındaki ilişkiyi belirlemek amacıyla yapılmıştır. Kişilik, bireyi iç ve dış dünyasında diğer insanlardan ayıran, bireyde belirli olay ve durumlarda değişmeyen, tutarlı olan davranışlarının bütünü olarak tanımlanmaktadır. Bireyler benzer 
ortamlarda benzer durumları birlikte yaşamalarına rağmen aynı şekilde davranmamaktadırlar. Bunun nedenleri araştırıldığında ise, her bireyin farklı özelliklerini kendisinde bulundurduğu kişilik unsurunun olduğu ortaya çıkmıştır. Bu çalışma kişilik kuramları arasında yer alan beş faktör kişilik özellikleri kuramı temel alınarak oluşturulmuştur. Duygusal emek kavramı, çalışan bireylerin belirlenen kurallar çerçevesinde duygularını yönlendirmesi sonucu verilen hizmette üstünlük sağlamayı ifade etmektedir.

Duygularını belirlenen kurallar çerçevesinde sergileyen çalışanların bu gösterimlerden sağladıkları fayda finansal olarak iyileşmeyi ifade etmekte iken, bu duyguların gösterimini isteyen örgütlerin faydası ise müşterilerin memnuniyetini, bağımılı̆̆ını artırarak organizasyonların karlarını, piyasa fiyatlarııı, imajını artırmak gibi birçok fayda sağlamaktır.

İşletmeler açısından emek kavramı bu zamana kadar fiziksel ve zihinsel emeği ifade etmekte iken günümüzde duygusal emek de işverenlerin çalışanlarından beklediği emek türü olarak karşımıza çıkmaktadır. Aşırı fiziksel emeğin sarf edilmesi sonucunda çalışanın bedenen yıprandığı görülmekte iken, çalışanın aşııı duygusal emek sarf etmesi sonucunda ise ruhsal olarak yıpranmalar görülmektedir.

Bu çalışma yapılırken duygusal emeğin en çok gerekli olduğu ve kullanıldığı meslek gruplarından biri olan özel eğitim ve rehabilitasyon merkezleri çalışanları araştırmanın uygulama alanı olarak seçilmiştir. Çalışma Kütahya ili Merkez ve tüm ilçelerinde bulunan özel eğitim ve rehabilitasyon merkezi çalışanlarına yapılmıştır. Yapılan çoklu regresyon analizi sonuçlarına göre, beş faktör kişilik özelliklerinin duygusal emek boyutlarından derinlemesine ve samimi davranış boyutunu açıkladığı etkilediği, yüzeysel davranı̧̧ boyutunu ise etkilemediği tespit edilmiştir. Yani; özel eğitim ve rehabilitasyon merkezi çalışanlarının kişilik özellikleri duygusal emek boyutlarından derinlemesine ve samimi davranış sergilemelerinin sebeplerinden biri iken, yüzeysel davranış sergilemelerinde kişilik özelliklerinin bir sebep olmadığı söylenebilir.

Hem regresyon hem de korelasyon analizleri sonuçlarına bakıldığında, duygusal emek boyutlarından yüzeysel davranışla hiçbir kişilik boyutunun ilişkili olmadığı sonucuna ulaşılmıştır. Bu sonuç, bireylerin hissetmedikleri halde kurumu tarafından belirlenen duyguları adeta rol yaparmışçasına sergilediği davranış olarak ifade edilen yüzeysel davranışın kişilik özellikleriyle açıklanamayacağı, aralarında ilişkinin olmamasının beklenen bir sonuç olduğu anlamına gelmektedir.

1983 yılında ilk defa duygusal emeği çalışan Hochschild yüzeysel davranışı, tiyatro sahnesinde aktörün oyun esnasında sergilediği role benzeterek açıklamıştır. Aktörden istenen elinde bulunan metne uygun şekilde rolünü yapmasıdır. Kişilik özelliklerini rolüne yansıtarak nasıl hissediyorsa o şekilde oyunu sergilemesi aktörden beklenmemektedir. Aslında Hochschild 1983 yılında yapmış olduğu çalışmasında yüzeysel davranışın kişilik özellikleri ile açıklanamayan ve kişilik özelliklerinden etkilenmeyen bir davranış türü olduğunu söylemek mümkündür. Bu nedenle yüzeysel davranış ile kişilik özellikleri arasında anlamlı ilişkilerin çıkmaması beklenen bir sonuç anlamına gelmektedir.

Literatüre bakıldığında yüzeysel davranış ve kişilik özellikleri bağlamında yapılan çalışmaların sonuçlarında burada ortaya çıkan sonuçlarla paralellik gösteren, aynı zamanda farklı sonuçlarında ortaya çıkarıldığı çalışmaları görmek mümkündür. Kim' in 2008 yılında otel çalışanlarına yapmış olduğu çalışmanın sonucunda beş faktör kişilik özellikleri boyutlarından duygusal dengesizlik boyutunun duygusal emek boyutlarından yüzeysel davranış ile aralarında anlamlı bir ilişkinin olduğu sonucuna ulaşılmıştır.

\section{KAYNAKLAR}

Adler, A. 2008, İnsanı Tanıma Sanatı, (çev:, Kamuran Sipal), Say Yayınları, İstanbul.

Apple, M T. 2011. The Big Five Personality Traits and Foreign Language Speaking Confidence Among Japanese Efl Students, Doctoral Dissertation, Temple University, Pennsylvania.

Ashforth, B.E. \& Humphrey, R.H. 1993, "Emotional Labor In Service Roles: The Influence of Identity", Academy of Management Review, Vol. 18 , No. 1, pp. 88-115.

Barrick, M.R. \& Mount, M.K. 1991, "The Big Five Personality Dimensions and Job Performance: A Meta-Analysis", Personnel Psychology, Vol. 44, No.1, pp. 1- 26. 
Barrick, M.R. \& Mount, M.K. 2005, “Personality Matters: Moving on to More Important Matters", Human Performance, Vol. 18, pp. 359372.

Basım, N.H. Beğenirbaş, M. ve Yalçın C.R. 2013, “Öğretmenlerde Kişilik Özelliklerinin Duygusal Tükenmeye Etkisi: Duygusal Emeğin Araclık Rolü", Kuram ve Uygulamada Eğitim Bilimleri, Cilt. 13, Sayı. 3, ss. 1477-1496.

Basım, N. ve Beğenirbaş, M. 2012, "Çalışma Yaşamında Duygusal Emek: Bir Ölçek Uyarlama Çalışması", Yönetim ve Ekonomi Dergisi, Cilt. 19, Sayı. 1, ss. $77-90$.

Begenirbaş, M. ve Yalçın C.R. 2012, "Öğretmenlerin Kişilik Özelliklerinin Duygusal Emek Gösterimlerine Etkileri”, Üniversitesi Sosyal Bilimler Dergisi, Cilt.9, Sayı.1, ss.47-65.

Benet - Martinez, V. \& John, O.P. 1998, "Los Cinco Garndes Across Cultures and Ethnic Groups: Multitrait Multimethod Analyses of the Big Five in Spains and English", Journal of Personality and Social Psychology, Vol. 75, No. 3, pp. $729-50$.

Buchanan, D.A. \& Huczynski, A. 1997, Organizational Behaviour, An Introductory Tex, Tertiary Printing, UK: Prentice Hall Europe.

Cheung, F.Y.L. \& Tang, C. S.K. 2009, "Emotional İntelligence, Affectivity, and Emotional Labor Strategies", Journal of Individual Differences, Vol. 30, No. 2, pp. 75-86.

Church, M.K. 1993, "Investigation and Measurement of Personality Structure in a Non-Western Culture: Relating Indigenous Philiphinne Dimensions to the Big Five Model", Doctoral Dissertation, Washington State University, Washington.

Cloninger, C.R. \& Svrakic, D.M. 2000, Personality disorders. B.J. Sadock ve V.A. Sadock, (Ed.), Comprehensive Textbook of Psychiatry (7th ed.)(235-298). Baltimore: Williams \& Williams

Costa, P.T. \& McCrae, R.R. 1992, Four Ways Five Factors Are Basic, (Akt: Selcen Demirkan), Personality and Individual Differences, Vol. 13, No. 6, pp. 653-665.

Diefendorff, J.M. Croyle, M.H. \& Gosserand, "R.H. 2005, The Dimensionality and Antecedents of Emotional Labor Strategies", Journal of Vocational Behavior, Vol. 66, No. 2, pp. 339-357.

Eroğlu, F. 2011, Davranıs Bilimleri, Beta Yayınları, İstanbul.

Grandey, A.A. 2000, "Emotion Regulation in The Workplace: A New Way to Conceptualize Emotional Labor", Journal of Occupational Health Psychology, Vol. 5, No. 1, pp. 95-110.

Grandey, A.A. 2003, “When the Show Must o on: Surface Acting and Deep Acting as Determinants of Emotional Exhaustion and Peer-rated Service Delivery", Academy of Management Journal, Vol. 46, pp. 86-96.

Hochschild, A.R. 1983, The Managed Heart Commercialization of Human Feeling, University of California Press, Berkeley, pp: 7 - 35.

Kiffin-Petersen, S.A., Catherine, L.J. \& Geoffrey, N.S. 2011, "The Big Five, Emotional Exhaustion and Citizenship Behaviors in Service Settings: The mediating Role of Emotional Labor", Personality and Individual Differences, Vol. 50, pp. 43-48.

Kim, H.J. 2008, "Hotel Service Providers' Emotional Labour: The Antecedents and Effects on Burnout”, International Journal of Hospitality Management, Vol. 27, No. 2, pp. 151-161.

Kruml, S.M. \& Geddes, D. 2000, "Exploring The Dimensions of Emotional Labor: The Heart of Hochschild's Work", Management Communication Quartely, Vol. 14, No.1, pp. 8-49.

Moody, M.C. 2007, "Adaptive Behvior in Intercultural Environments: The Relationship Between Cultural Intelligence Factors and Big Five Personality Traits", Doctoral Dissertation, George Washington University, Washington.

Perry, S.R. 2003, "Big Five Personality Traits and Work Drive as Predictors of Adolescent Academic, Performance", Doctoral Dissertation, The University of Tennessee, Tennesseee.

Schmitt, D.P., Allik, J., McCrae, R.R. \& Benet - Martinez, V. 2007, "The Geographic Distribution of Big Five Personality Traits: Patterns and Profiles of Human Self-Description Across 56 Nations", Journal of Cross-Cultural Psychology, Vol. 38, pp. $172-212$

Shaye, A. 2009, "Infidelity in Dating Relationships: Do Big Five Personality Traits and Gender Influence Infidelity?", Doctoral Dissertation, Alliant International University, California.

Somer, O. \& Lewis R.G. 1999, "The Structure of Turkish Trait Descriptive Adjectives", Journal of Personality and Social Psychology, Issue.76, pp. 431- 450 .

Sümer, N. ve Sümer, H.C., 2005, Beş Faktör Kişilik Özellikleri Ölçeği, (Yayınlanmamış çalışma).

Sümer, N., Lajunen, T. \& Özkan, T. 2005, "Big Five Personality Traits as the Distal Predictors of Road Accident Involvement", Traffic and Transport Psychology, (Edt: G. Underwood), pp. 215 - 227.

Tews, M.R. \& Glomb, T.M. 2004, "Emotional labor and the five factor model of Personality" Cornell University Center for Hospitality Research Paper, http://www.hotelschool.cornell.edu/chr/pdf/showpdf/laborfivefactor.pdf.(25.10.2014) 
Trouba, E.J. 2007, "A Person-Organızatıon Fit Study of the Big Five Personality Model and Attraction to Organizations With Varying Compensation System Characteristics", Doctorta Dissertation, DePaul University, Chicago.

Yoon, K. 1997, "General Mental Ability and the Big Five Personality Dimensions: An Investigation of the Cross-Cultural Generalizability of Their Construct and Criteron-Related Validities in Korea", Doctoral Dissertation, The University of lowa, lowa. 